Omni-Akuatika 12 (2): 114-124, 2016
ISSN: 1858-3873 print / 2476-9347 online
Research Article

\title{
Profil Suhu, Oksigen Terlarut, dan pH Secara Vertikal Selama 24 Jam di Danau Kelapa Gading Kabupaten Asahan Sumatera Utara
}

\author{
Eva Lia Risky Sinaga ${ }^{1}$, Ahmad Muhtadi ${ }^{1,},{ }^{\star}$ Darma Bakti ${ }^{1}$ \\ ${ }^{1}$ Program Studi Manajemen Sumberdaya Perairan, Fakultas Pertanian, Universitas Sumatera Utara, Medan, \\ Indonesia 20155 \\ Corresponding author ${ }^{*}$ : ahmad.muhtadi@usu.ac.id \\ Received 25 June 2016; Accepted 15 October 2016; Available online 30 November 2016
}

\begin{abstract}
Lake Kelapa Gading is an artificial lake located in Asahan district of North Sumatra province. The purpose of this study was to determine: 1) description of conditions of temperature, dissolved oxygen and $\mathrm{pH}$ vertically in the water for 24 hours, 2) production and consumption of oxygen in the waters of Lake Kelapa Gading. The study was conducted in March-April 2016 with preliminary and main research activities. There are three observation stations are stations 1 (near KJA), station 2 (the area near the settlement) and station 3 (outlet). The measured temperature ranges from $30-35{ }^{\circ} \mathrm{C}$. dissolved oxygen highest in the surface waters of $5.12 \mathrm{mg} / \mathrm{I}$ during the afternoon and the lowest occurred at a depth of compensation of $0.64 \mathrm{mg} / \mathrm{I}$ when the weather is rainy. The measured $\mathrm{pH}$ value ranging between 6-9. In general there is a decrease in temperature, dissolved oxygen, and $\mathrm{pH}$ with increasing depth. The highest percent saturation of $71.30 \%$ in the surface waters. Comparison between photosynthesis to respiration indicates that there has been a deficit in respiration is greater than the value of photosynthesis. dissolved oxygen concentration has reached a deficit at a depth of $36.5 \mathrm{~cm}$ to reach at night.
\end{abstract}

Keywords: dissolved oxygen, lake, $\mathrm{pH}$, saturation, temperature.

\section{Pendahuluan}

Suhu, oksigen terlarut dan $\mathrm{pH}$ di perairan merupakan parameter kualitas air yang sangat penting terkait dengan kehidupan organisme perairan (Effendi, 2003). Ketiganya merupakan parameter kunci kualitas air yang mengendalikan distribusi dan sebaran organisme di perairan (Nakamura dan Hayakawa, 1991; Araoye, 2009; Pal et al., 2014). Stratifikasi vertikal suhu, oksigen dan $\mathrm{pH}$ di perairan danau dapat menunjukkan dinamika perairan, potensi produktivitas dan evolusi kimia di dalamnya (Araoye, 2009; Lukman dan Ridwansyah, 2010).

Stum (1985) mengemukakan bahwa stratifikasi suhu di suatu perairan berperan penting dalam proses ekologis badan air. Lebih lanjut (Ambrosetti dan Barbanti, 2001; Katsev et al., 2014) menyebutkan, profil suhu secara vertikal di danau diperlukan untuk menentukan kandungan panas di perairan, lapisan termoklin dan percampuran massa air di perairan.

Sementara itu, Oksigen terlarut sangat penting untuk respirasi, pertumbuhan, perkembangbiakan, proses metabolisme oleh seluruh jasad hidup organisme akuatik. Selain itu okesigen terlarut juga berperan dalam dekomposisi bahan organik di perairan (Hamilton \& Schladow, 1994). Dinamika dan penyebaran oksigen pada danau-danau berstratifikasi panas dikendalikan oleh kombinasi kondisi kelarutan, hidrodinamika, masukan dari fotosintesis, dan kehilangan untuk oksidasi metabolis dan kimia (Wetzel, 1983; Lukman dan Ridwansyah, 2010). Profil suhu dan oksigen secara vertikal akan memberikan informasi penting terkait turbulensi dan pengadukan serta penurunan oksigen pada lapisan hipolimnion (Barbanti et al. 1981; Pal et al., 2014)

Oksigen terlarut dan $\mathrm{pH}$ mempengaruhi secara langsung atau tidak langsung parameter limnologi lainnya seperti viskositas, total padatan terlarut dan konduktivitas (Whitney, 1942); yang semuanya merupakan parameter fisik dan kimia yang sangat penting dalam pengelolaan perairan (Araoye et al., 2007).

Danau Kelapa Gading (DKG) merupakan danau buatan yang terdapat di Kabupaten Asahan Provinsi Sumatera Utara. Danau ini memiliki luas 1,19 ha dengan 
kedalaman maksimum 2,15 $\mathrm{m}$ dan kedalaman rata-rata 1,26 $\mathrm{m}$ (Ridoan et al., 2016). Fungsi utama danau ini adalah sebagai resapan air. Danau ini juga sebagai tempat rekreasi, pemancingan dan pemeliharaan ikan baik di keramba maupun di dalam danau itu sendiri.

Penelitian terkait suhu, oksigen terlarut, dan $\mathrm{pH}$ di Danau Kelapa Gading belum pernah dilakukan, sehingga diperlukan penelitian mengenai profil vertikal suhu, oksigen terlarut, dan pH di Danau Kelapa Gading. Tujuan dari penelitian ini adalah untuk mengetahui gambaran kondisi suhu, ketersediaan, oksigen terlarut dan $\mathrm{pH}$ di perairan Danau Kelapa Gading selama 24 jam.

\section{Metode Penelitian}

Waktu dan lokasi penelitian

Penelitian ini dilaksanakan di Danau Kelapa Gading, Kabupaten Asahan, Sumatera Utara. Danau ini terletak di Kelurahan Kisaran Naga Kecamatan Kisaran Timur. Stasiun I merupakan daerah danau yang dipengaruhi oleh aktivitas Keramba Jaring Apung (KJA). Stasiun II ini merupakan daerah dekat dengan pemukiman dan aktivitas wisata. Stasiun III merupakan daerah outlet. Penelitian ini berlangsung pada bulan Maret sampai dengan April 2016. Peta lokasi penelitian di Danau Kelapa Gading dapat dilihat pada Gambar 1.

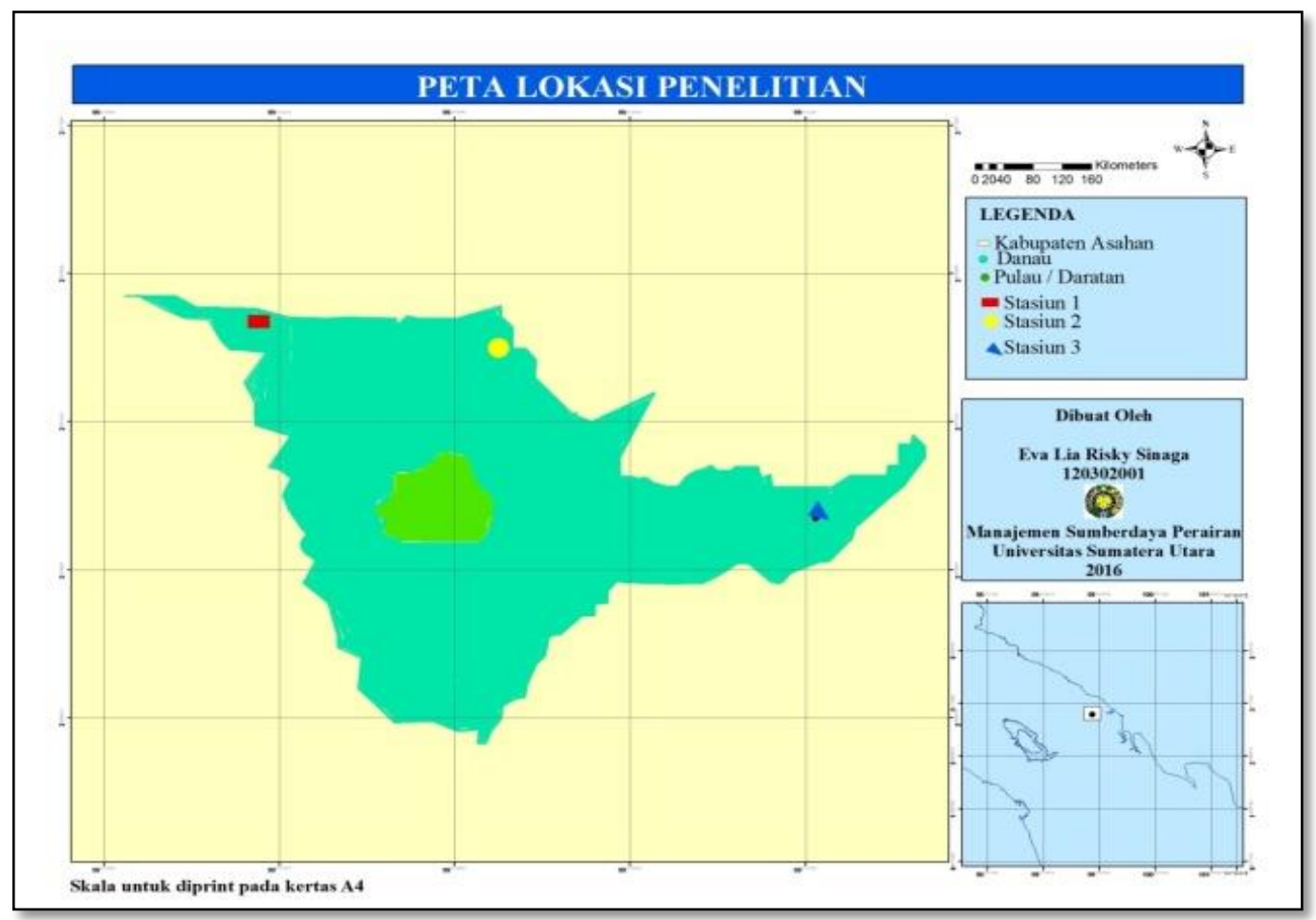

Gambar 1. Peta Lokasi Danau Kelapa Gading

\section{Alat dan Bahan}

Alat-alat yang digunakan adalah GPS, Van Dorn Water Sampler dengan volume 5 liter, Secchi disk, botol Winkler $125 \mathrm{ml}, \mathrm{pH}$ meter, Lux meter, termometer, pipet tetes, labu Erlenmeyer, coolbox, jarum suntik dan alat tulis. Bahan-bahan yang digunakan adalah berupa sampel air dan bahan-bahan pereaksi seperti $\mathrm{MnSO}_{4}, \mathrm{H}_{2} \mathrm{SO}_{4}, \mathrm{KOH}-\mathrm{KI}, \mathrm{Na}_{2} \mathrm{~S}_{2} \mathrm{O}_{3}$, Amylum, tissue, dan kertas label.

\section{Penelitian Pendahuluan}

Penelitian pendahuluan ini dilakukan pada tanggal 12 Maret 2016 dengan pengukuran di waktu pagi, siang, dan sore. Kegiatan ini untuk mengetahui kedalaman kompensasi yaitu dengan mengukur kecerahan perairan. Selanjutnya dimasukkan kedalam persamaan Beer-Lambert tahun 1983 in Effendi (2003) pada persamaan:

$$
\begin{aligned}
& \mathrm{k} D=\frac{1,7}{\mathrm{Zs}} \\
& Z c=\frac{4,6}{\mathrm{k} D}
\end{aligned}
$$

Keterangan :

$\mathrm{kD}=$ Koefisisen peredupan cahaya matahari

Zs = Kedalaman Secchi

$E z=$ Radiasi pada kedalaman tertentu

$\mathrm{E} 0=$ Radiasi di permukaan

$\mathrm{Zc}=$ Kedalaman kompensasi dalam $\mathrm{cm}$ 
Penelitian Utama

Pengukuran suhu, DO dan $\mathrm{pH}$

Suhu, DO dan $\mathrm{pH}$ diukur secara vertikal pada 3 kedalaman berdasarkan pada hasil penelitian pendahuluan. Stasiun 1, kedalaman $0 \mathrm{~cm}$ sebagai lapisan permukaan, kedalaman $33,5 \mathrm{~cm}$ sebagai lapisan dari perwakilan batas keping sechi, kedalaman 92 $\mathrm{cm}$ untuk kedalaman kompensasi. Stasiun 2 kedalaman $0 \mathrm{~cm}$ sebagai lapisan permukaan perairan, kedalaman $36,5 \mathrm{~cm}$ untuk perwakilan batas keping sechi dapat terlihat, dan kedalaman $115 \mathrm{~cm}$ untuk kedalaman kompensasi. Stasiun 3 sama dengan stasiun 2 dikarenakan nilai kecerahan pada saat penelitian pendahuluan adalah sama.

Pengambilan sampel air untuk analisis suhu, DO dan $\mathrm{pH}$ dengan menggunakan Van Dorn Water Sampler. Selanjutnya langsung diukur suhu, DO dan $\mathrm{pH}$. Pengukuran oksigen terlarut juga digunakan untuk menduga besarnya produksi oksigen yang berasal dari proses fotosintesis dan besarnya pemanfaatan oksigen untuk respirasi dan dekomposisi mikroorganisme.

Pengukuran fotosintesis dan respirasi dilakukan pada setiap kedalaman menggunakan 3 botol, 1 botol gelap dan 1 botol terang, serta 1 botol inisial. Botol gelap dan botol terang diinkubasi selama 4 jam. Kandungan oksigen terlarut pada botol inisial langsung diukur sehingga menggambarkan oksigen saat itu. Pada botol terang terjadi proses fotosintesis, respirasi, dan dekomposisi, sedangkan pada botol gelap terjadi respirasi dan dekomposisi. Pengamatan terhadap besarnya tingkat fotosintesis hanya dilakukan pada siang hari. Besarnya tingkat respirasi dan dekomposisi dilakukan sepanjang hari selama 24 jam.

Suhu diukur dengan menggunakan termometer. DO diukur dengan metode winkler dan $\mathrm{pH}$ diukur dengan $\mathrm{pH}$ meter. Dalam penelitian ini, pengukuran suhu, DO dan $\mathrm{pH}$ dilakukan setiap empat jam sekali dalam kurun waktu 24 jam. Waktu inkubasi selama 4 jam diharapkan dapat mewakili waktu pengamatan baik pada siang hari ataupun pada malam hari. Hal ini akan diperoleh untuk pengamatan pada siang hari sebanyak tiga kali amatan dan pada malam hari tiga amatan pula. Analisis

Kecerahan, kekeruhan dan intensitas cahaya

Kecerahan diukur dengan menggunakan keping sechi sebanyak satu kali dalam 24 jam, yaitu ketika cahaya optimum antara pukul 10.00-14.00. Pengukuran kecerahan dilakukan pada saat matahari tidak terhalangi ataupun tertutup awan. Kekeruhan diukur dengan mengambil sampel air danau setiap stasiun selama 1 kali 24 jam, kemudian dimasukkan dalam botol sampel 1 liter dan didinginkan. Analisis dilakukan di Laboratorium BTKLPP, Medan. Intensitas cahaya diukur dengan menggunakan alat Lux Meter Pengukuran nilai intensitas cahaya dilakukan sekali dalam 24 jam pada saat cahaya optimum.

\section{Analisis Data}

Analisis Profil Suhu, DO dan $\mathrm{pH}$

Data yang didapat dari hasil pengukuran suhu, DO, dan $\mathrm{pH}$ kemudian ditampilkan dalam bentuk tabel dan grafik secara vertikal dengan bantuan microsoft excel.

\section{Analisis Penentuan Persen (\%) Saturasi Oksigen}

Kejenuhan oksigen di perairan dinyatakan dengan persen saturasi (Wetzel dan Likens, 1991).

Keterangan :

$$
\% \text { Saturasi }=\frac{\text { Do }}{\text { Dot }} \times 100 \%
$$

DO = Konsentrasi oksigen terlarut (mg/l)

DOt $=$ Konsentrasi oksigen terlarut secara teori (mg/l)

\section{Analisis Besarnya Fotosintesis dan Respirasi}

Untuk menghitung besarnya nilai fotosintesis dan nilai respirasi digunakan formula sebagai berikut (Wetzel dan Likens, 1991)::

$$
\begin{gathered}
N P P=(L-I) / t \\
R=(I-D) / t \\
\text { GPP }=(L-D) / t
\end{gathered}
$$

\begin{tabular}{|c|c|}
\hline NPP & $\begin{array}{l}\text { : Net Primary Productivity } \\
\left(\mathrm{mgO}_{2} / \mathrm{l} / \mathrm{jam}\right)\end{array}$ \\
\hline $\mathrm{R}$ & $\begin{array}{l}\text { : Respirasi dan dekomposisi } \\
\left(\mathrm{mgO}_{2} / \mathrm{l} / \mathrm{jam}\right)\end{array}$ \\
\hline GPP & $\begin{array}{l}\text { : Gross Primary Productivity } \\
\left(\mathrm{mgO}_{2} / \mathrm{l} / \mathrm{jam}\right)\end{array}$ \\
\hline L & $\begin{array}{l}\text { :Konsentrasi oksigen dalam } \\
\text { terang }\left(\mathrm{mgO}_{2} / \mathrm{l}\right)\end{array}$ \\
\hline D & $\begin{array}{l}\text { Konsentarsi oksigen dalam } \\
\text { gelap }\left(\mathrm{mgO}_{2} / \mathrm{l}\right)\end{array}$ \\
\hline l & $\begin{array}{l}\text { Konsentrasi oksigen dalam } \\
\text { inisial }\left(\mathrm{mgO}_{2} / \mathrm{l}\right)\end{array}$ \\
\hline$t$ & : Lama inkubasi (jam) \\
\hline
\end{tabular}

Keterangan : 


\section{Hasil Dan Pembahasan}

\section{Sebaran Suhu Vertikal Selama 24 Jam}

Berdasarkan hasil pengukuran suhu tertinggi dari pagi hingga sore hari adalah $35^{\circ} \mathrm{C}$ pada stasiun 1 pukul 14.00 WIB. Pada stasiun 2, suhu tertinggi didapatkan bernilai $34,5^{\circ} \mathrm{C}$ pukul 18.00 H1 (Hari pertama). Stasiun 3, suhu tertinggi yaitu sebesar $34^{\circ} \mathrm{C}$ pada pukul 18.00. Suhu tertinggi di setiap stasiun didapatkan pada saat pengukuran di lapisan permukaan perairan dan terjadi pada saat cahaya matahari optimum yaitu sekitar pukul 14.00 sampai 18.00 WIB.

Suhu di malam hari sampai pagi di setiap stasiun hampir sama yaitu berkisar antara $30{ }^{\circ} \mathrm{C}$ sampai $33{ }^{\circ} \mathrm{C}$. Suhu terendah didapatkan pada stasiun 1 pukul 06.00 di kedalaman $33 \mathrm{~cm}$ dan $92 \mathrm{~cm}$. Nilai suhu yang didapatkan di setiap kedalaman tidak jauh berbeda terutama pada kedalaman lapisan permukaan dan lapisan batas kecerahan karena pada DKG tidak terdapat lapisan termoklin (Adiwilaga et al., 2009).

Pengamatan suhu di DKG berkisar paling tinggi pada saat siang hari, hal ini terjadi dikarenakan pada saat pengamatan cahaya matahari optimum dan keadaan cuaca sangat cerah sehingga membuat suhu di lapisan perairan menjadi tinggi. Menurut Effendi (2003), suhu suatu badan air dipengaruhi oleh musim, lintang, ketinggian dari permukaan laut, waktu dalam hari, penutupan awan dan kedalaman perairan. Berdasarkan waktu pengamatan, suhu yang ada di perairan juga mengalami penurunan dari pengamatan pertama yaitu pukul 18.00. Suhu mengalami penurunan sampai dengan pengamatan pukul 06.00 pagi dan meningkat kembali di siang hari sampai pengamatan waktu terakhir yaitu pukul $18.00 \mathrm{H} 2$. Menurut Chang dan Ouyang (1988), dampak dari perubahan suhu memiliki potensi dengan tingkat konsumsi oksigen yang kecil, karena suhu cukup konstan. Perubahan harian maksimum suhu tidak lebih dari 2 atau 3 derajat.
Suhu hasil penelitian di DKG mengalami penurunan dengan bertambahnya kedalaman. Walapun perubahan tersebut tidak begitu drastis. Hasil penelitian sebelumnya tercatat yang hal yang sama seperti dilaporkan oleh Adiwilaga et al., (2009), Araoye (2009), Lukman dan Ridwansyah (2010), Read dan Rose (2013), Pal et al., (2014). Pada danaudanau yang terbentuk secara vulkanis, suhu di dasar tidak selalu lebih rendah dibanding permukaan. Akan tetapi bisa lebih tinggi seperti yang dilaporkan oleh Katsev et al., (2014) di Danau Kivu di Kongo. bahkan di danau Toba Sendiri pada kedalaman $400 \mathrm{~m}$, suhu mengalami kenaikan hingga mendekati suhu permukaan (Lukman dan Rodwansyah, 2009). Hal ini dikarenakan Danau toba merupakan danau yang terbentuk secar vulkanik dan merupakan kaldera dari gunung Toba (Herdendorf, 1982).

Berdasarkan stratifikasi suhu di DKG tidak ada lapisan termoklin. Dengan demikian tidak terdapat perbedaan suhu yang mencolok antara permukaan dan dasar perairan. Hal ini dikarenakan danau yang dangkal (maksimum 2,15 $\mathrm{m}$ ) dan akan mudah mengalami pengadukan (Ridoan et al., 2016). Sangat berbeda dengan Danau Toba yang mencapai kedalaman maksimum $508 \mathrm{~m}$ dengan lapisan termoklin diperkirakan pada kedalaman 0-30 m (Lukman dan Ridwansyah, 2010). Akan tetapi walaupun Danau Rudrasagar di India tergolong dangkal $(6 \mathrm{~m})$, akan tetapi perubahan suhu antara permukaan dengan dasar cuku besar mencapai $3{ }^{\circ} \mathrm{C}$ (Pal et al., 2014), sementara di DKG hanya sekitar $1{ }^{\circ} \mathrm{C}$. Hal ini menunjukkan ada pengaruh iklim dan kondisi geografis danau yang dapat mempengaruhi fluktuasi suhu di perairan danau ( $\mathrm{Pal}$ et al., 2014). Beda halnya dengan hasil penelitian dari Lukman dan Ridwansyah (2009) mendapatkan penurunan suhu hingga $3{ }^{\circ} \mathrm{C}$ bagian dasar tapi sampai kedalaman $400 \mathrm{~m}$ di perairan Danau Toba. 

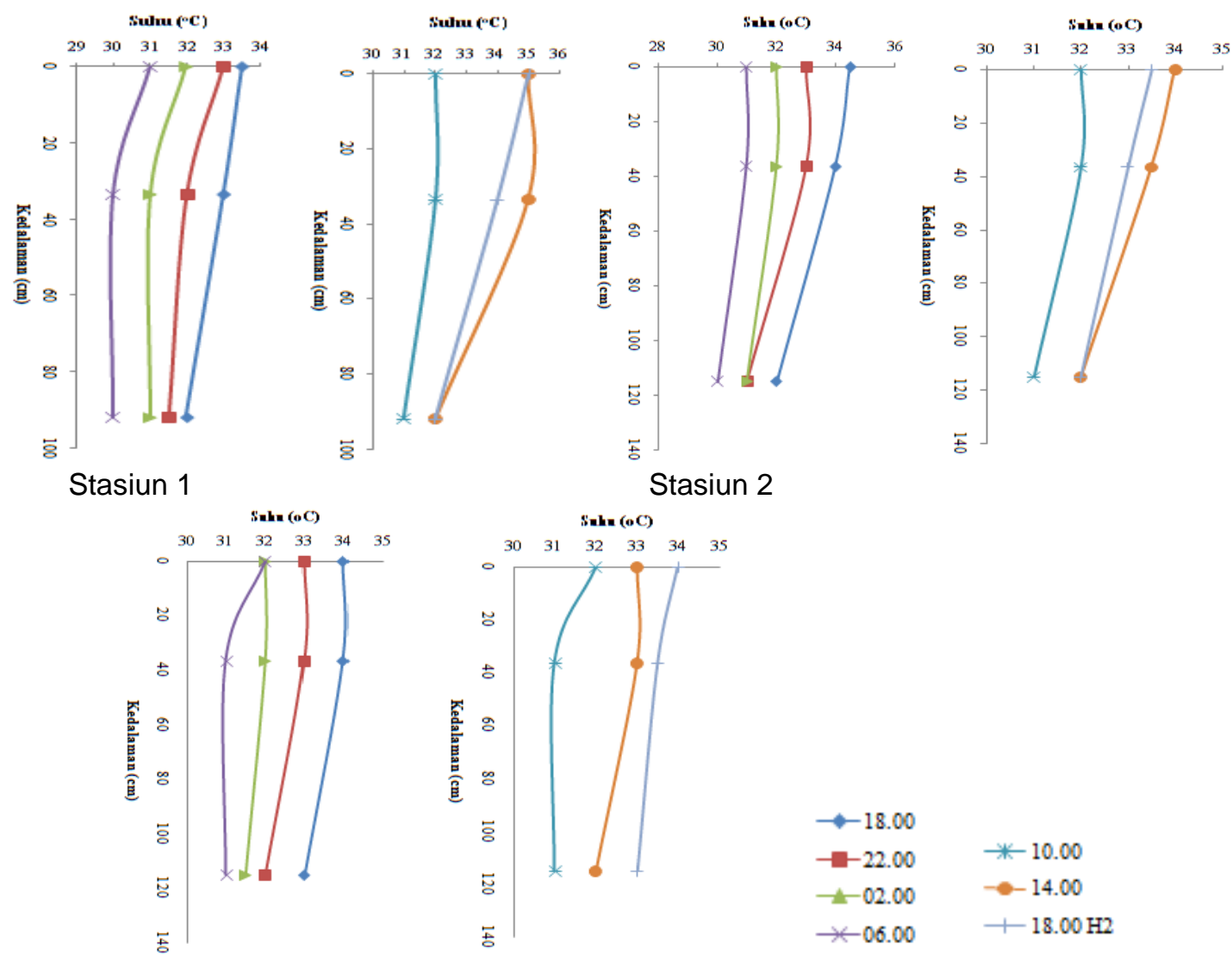

Stasiun 3

Gambar 2. Sebaran suhu secara vertikal selama 24 jam

Distribusi vertikal oksigen terlarut selama 24 Jam

Oksigen terlarut yang diamati memiliki nilai yang berbeda antara siang hari dan malam hari. Konsentrasi oksigen terlarut tertinggi di dapatkan pada lapisan permukaan perairan danau dan saat sore hari yaitu pada pengukuran pukul 18.00 di setiap stasiunnya. Hal ini disebabkan karena pada saat pengukuran pukul 18.00, cahaya matahari masih optimum dan proses fotosintesis oleh fitoplankton masih dapat berlangsung. Konsentrasi oksigen terlarut paling rendah dijumpai di stasiun 3 yaitu sebesar $0,64 \mathrm{mg} / \mathrm{l}$ pada saat pengamatan pukul 10.00 dan berada di kedalaman kompensasi $(115 \mathrm{~cm})$.

Kandungan DO (Dissolved Oxygen) selama pengamatan pada 3 stasiun di kedalaman permukaan, batas keping sechi, dan kedalaman kompensasi menunjukkan hasil yang tidak jauh berbeda antara ketiga stasiun per kedalamannya. Kosentrasi DO selama 24 jam stasiun 1 pada lapisan permukaan perairan berkisar dari 2,16 mg/l yang terjadi pukul 06.00 sampai $5,12 \mathrm{mg} / \mathrm{l}$ yang terjadi pada pukul $18.00 \mathrm{H} 1$ (Hari pertama), pada kedalaman batas keping sechi berkisar dari 2,08 mg/l sampai dengan 4,64 $\mathrm{mg} / \mathrm{l}$ dan untuk kedalaman kompensasi memiliki DO terendah yaitu sebesar $2,00 \mathrm{mg} / \mathrm{l}$ sampai dengan $4 \mathrm{mg} / \mathrm{l}$. Stasiun 2 memiliki konsentrasi DO tertinggi yaitu pada lapisan permukaan pukul $18.00 \mathrm{H} 1$ sebesar $4,24 \mathrm{mg} / \mathrm{l}$ dan DO terendah pada kedalaman kompensasi $(115 \mathrm{~cm})$ pukul 06.00 sebesar $1,52 \mathrm{mg} / \mathrm{l}$. 


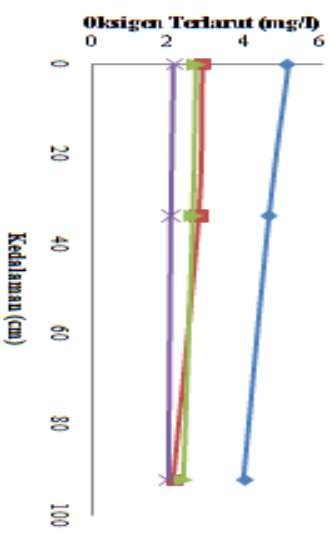

Stasiun 1

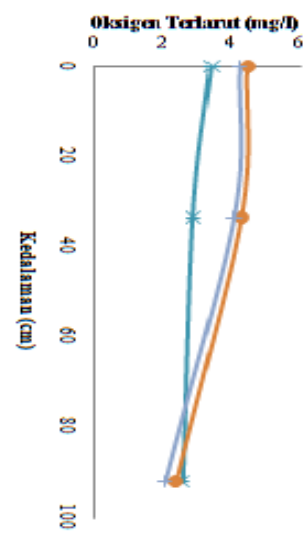

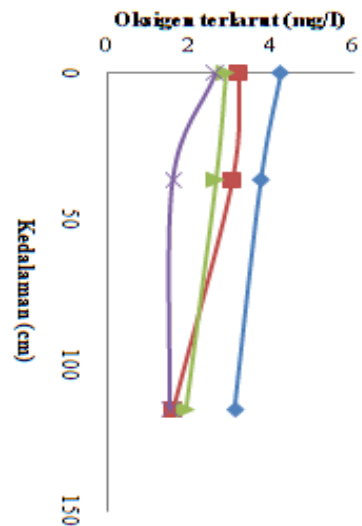

Stasiun 2
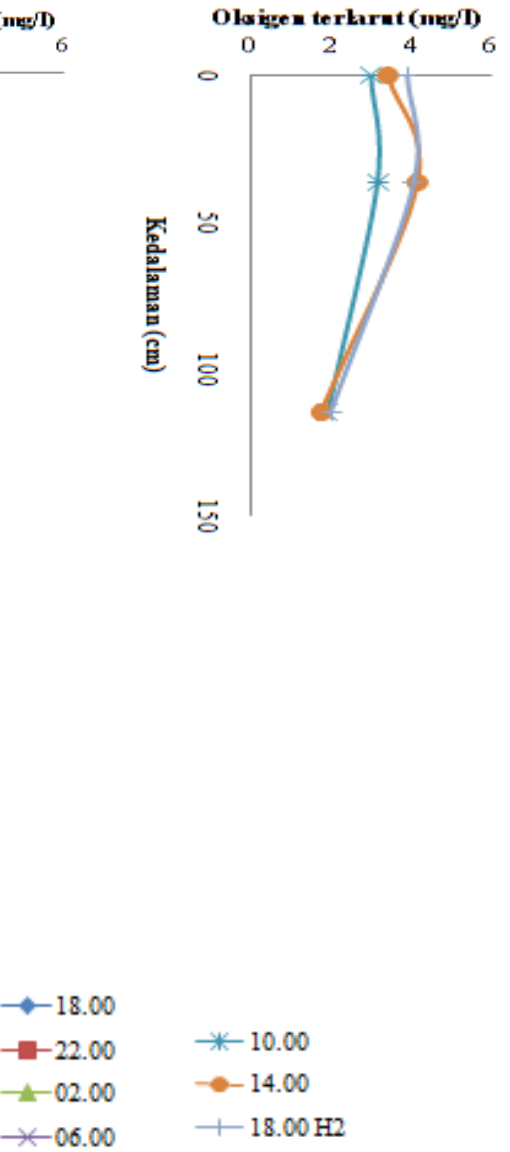

$\rightarrow 06.00$
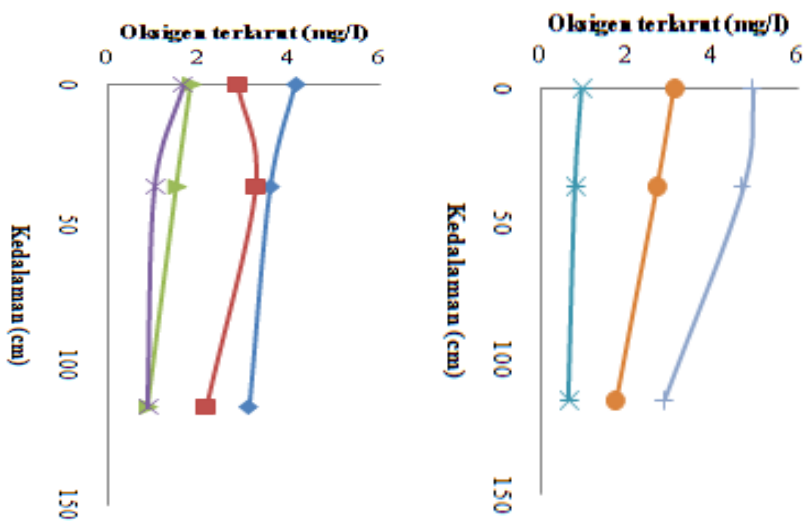

Stasiun 3

Gambar 3. Distribusi oksigen terlarut (mg/l) secara vertikal selama 24 jam

Konsentrasi oksigen terlarut hasil penelitian di DKG mengalami penurunan dengan bertambahnya kedalaman. Hasil penelitian sebelumnya tercatat yang hal yang sama seperti dilaporkan oleh Adiwilaga et al., (2009), Araoye (2009), Lukman dan Ridwansyah (2010), Pal et al., (2014), Siagian dan Simarmata $(2014,2015)$,. Lebih lanjut Adiwilaga et al., (2009) menyebutkan pada perairan stagnan seperti danau atau waduk, kondisi oksigen terlarut pada umumnya mengalami stratifikasi. Konsentrasi oksigen terlarut pada umumnya mengalami penurunan dengan bertambahnya kedalaman. Hal ini diduga terjadi karena suplai oksigen dari proses fotosintesis dan difusi menurun (Reebs, 2009). Selain itu, pada lapisan dasar perairan terjadi dekomposisi bahan organik (Adiwilaga et al., 2009; Lukman dan Ridwansyah, 2010).

Konsentrasi oksigen terlarut tertinggi pada masing-masing stasiun berada pada lapisan permukaan perairan. Hal ini dikarenakan adanya cahaya matahari di lapisan permukaan perairan yang diamati sehingga membantu proses fotosintesis dalam mensuplai oksigen ke perairan (Salmin, 2005). Berdasarkan hasil pengamatan fitoplankton juga menunjukkan secara umum fitoplankton paling tinggi pada permukaan, kecuali stasiun 1 dan akan semakin berkurang dengan bertambahnya kedalaman. Hal ini juga seperti yang dijelaskan dan ditemukan oleh Adiwilaga et al., (2009) serta Siagian dan Simarmata (2014, 2015).

Menurut Araoye (2009), difusi oksigen ke dalam perairan alami lambat, kecuali dalam kondisi turbulensi yang kuat maka sebagian sumber penting oksigen adalah melalui proses fotosintesis oleh organisme dan tanaman air. Pada waktu pengamatan, pukul 06.00 merupakan waktu konsentrasi oksigen terlarut paling rendah dikarenakan mulai pukul 18.00 tidak terjadi lagi proses fotosintesis dan semua organisme mengkonsumsi oksigen untuk respirasi sepanjang malam (Adiwilaga et al., 2009).

Berdasarkan nilai distribusi vertikal DO rata-rata selama 24 pengamatan, DKG memiliki tipe perairan clinograde (Goldman dan Horne, 1983). Tipe clinograde terjadi pada danau dengan kandungan unsur hara dan bahan organik 
yang tinggi (eutrofik) (Adiwilaga, et al., 2009). Hasil penelitian Muhtadi et al., (2016) kesuburan perairan DKG termasuk eutrofik.

\section{Distribusi Vertikal Derajat Keasaman $(\mathrm{pH})$}

Nilai $\mathrm{pH}$ pada stasiun 1 terendah pada pengamatan pukul 06.00 yaitu sebesar $7,8 \mathrm{di}$ lapisan permukaan, 7,6 di kedalaman $33,5 \mathrm{~cm}$ dan 7,4 di kedalaman $92 \mathrm{~cm}$. pH tertinggi terjadi pada saat hari kedua pengamatan yaitu pukul 18.00 sebesar 9,3. Pada stasiun 2, selama pengamatan 24 jam menunjukkan tidak adanya nilai $\mathrm{pH}$ yang bersifat asam. Nilai $\mathrm{pH}$ terendah berada pada kedalaman $115 \mathrm{~cm}$ pada saat pengamatan pukul 22.00 sebesar 7,1 dan $\mathrm{pH}$ tertinggi berada pada lapisan permukaan saat pengamatan pukul 14.00 sebesar 9,3

Nilai $\mathrm{pH}$ di stasiun 3 pada lapisan permukaan, nilai $\mathrm{pH}$ tertinggi mencapai 9,1 pada pukul 22.00, kemudian menurun sampai pukul 10.00 dan meningkat kembali sampai

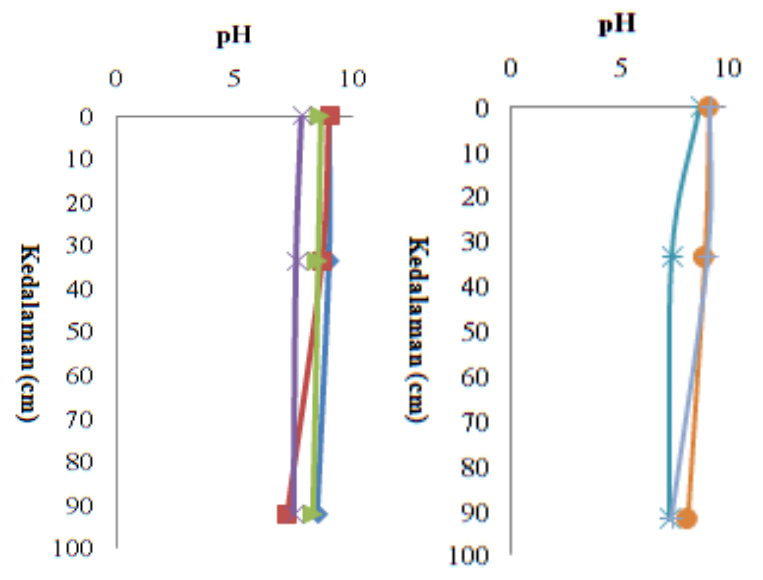

Stasiun 1

pukul $18.00 \mathrm{H} 2$. Nilai $\mathrm{pH}$ yang terukur menunjukkan terjadinya penurunan di setiap kedalaman pada saat pukul 02.00 sampai pukul 06.00. Selanjutnya mulai pukul 10.00 sampai 18.00 terjadi peningkatan $\mathrm{pH}$ dari asam ke basa.

Secara umum nilai $\mathrm{pH}$ yang diamati juga terlihat mengalami penurunan seiring dengan bertambahnya kedalaman perairan. Kondisi ini juga seperti yang didapatkan oleh Adiwilaga et al., (2009) dan Araoye (2009). Pada umumnya, nilai $\mathrm{pH}$ pada siang hingga sore hari lebih tinggi daripada malam hingga pagi hari. Kondisi ini diduga akibat terjadinya proses fotosintesis pada siang hari (Adiwilaga et al., 2009). Lebih lanjut Araoye (2009) menjelaskan menurunnya $\mathrm{pH}$ pada bagian dasar adalah meningkatnya aktivtas mikroba untuk menguraikan bahan organik sehingga $\mathrm{O}_{2}$ menurun dan $\mathrm{CO}_{2}$ meningkat. Meningkatnya $\mathrm{CO}_{2}$ akan membuat perairan menjadi lebih asam ( $\mathrm{pH}$ menurun).

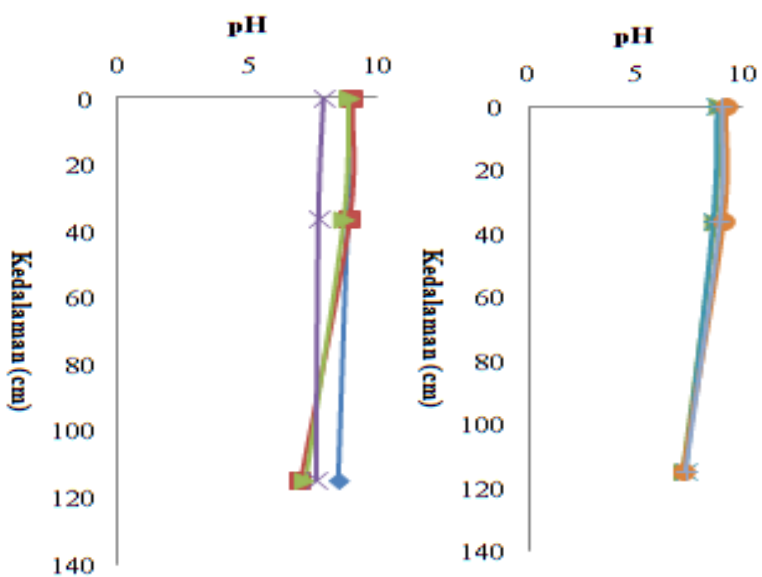

Stasiun 2
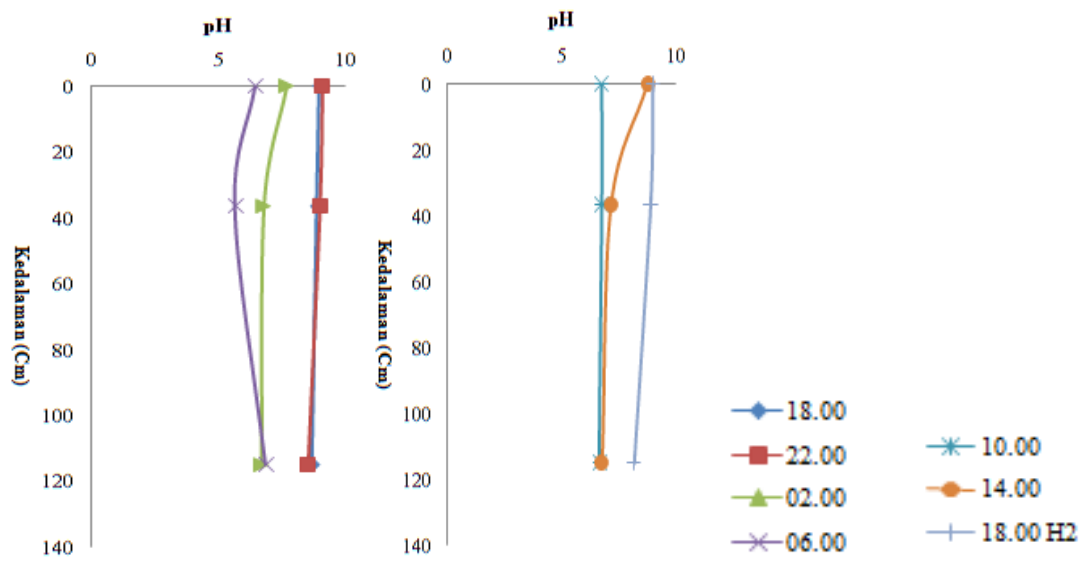

Stasiun 3

Gambar 4. Profil pH secara vertikal selama 24 Jam di Danau Kelapa Gading 


\section{Saturasi Oksigen Terlarut (\%)}

Berdasarkan data yang di peroleh persen saturasi yang tertinggi berada pada lapisan permukaan perairan stasiun 1 mencapai nilai persen saturasi sebesar $71,30 \%$ pada waktu pengamatan pukul 18.00 $\mathrm{H} 1$. Persen saturasi stasiun 1 terendah yang didapat berada pada lapisan kedalaman kompensasi yaitu sebesar $26,45 \%$ terjadi pada pengamatan pukul 06.00 WIB.

Kondisi saturasi DO pada stasiun 2 memiliki nilai persen saturasi tertinggi dan terendah pada kedalaman dan waktu pengamatan yang sama dengan stasiun 1 . Nilai saturasi terendah terjadi pada pukul 06.00 WIB di kedalaman $115 \mathrm{~cm}$. Hal ini terjadi dikarenakan konsentrasi oksigen terlarut pada saat itu juga rendah. Saturasi tertinggi terjadi pada pengamatan pukul 18.00 WIB yang mencapai $60,05 \%$ di lapisan permukaan perairan. Saturasi (\%) pada stasiun selanjutnya yaitu stasiun 3 ditampilkan pada Gambar 5.
Pengamatan pada stasiun 3 berbeda dengan stasiun 1 dan stasiun 2. Berdasarkan hasil pengamatan kondisi persen saturasi pada stasiun 3 memiliki nilai terendah pada waktu pengamatan pukul 10.00 di kedalaman kompensasi yaitu sebesar $8,61 \%$. Nilai saturasi tertinggi didapatkan pada pengamatan pukul $18.00 \mathrm{H} 2$ di lapisan permukaan perairan dimana pada saat pukul 18.00 masih dalam kondisi ada cahaya matahari dan fotosintesis sehingga membuat oksigen terlarut menjadi tinggi.

Pengamatan selama 24 jam pada stasiun 1, stasiun 2 dan stasiun 3 menunjukkan hasil tidak adanya kondisi oksigen yang mencapai saturasi di setiap kedalamannya dan waktu pengamatan. Hal yang sama di dapatan oleh Adiwilaga et al., (2009) pada Waduk Jatiluhur. Hal ini diduga disebabkan oleh terhambatnya proses fotosintesis yang menyebabkan menurunnya produksi oksigen oleh fitoplankton.

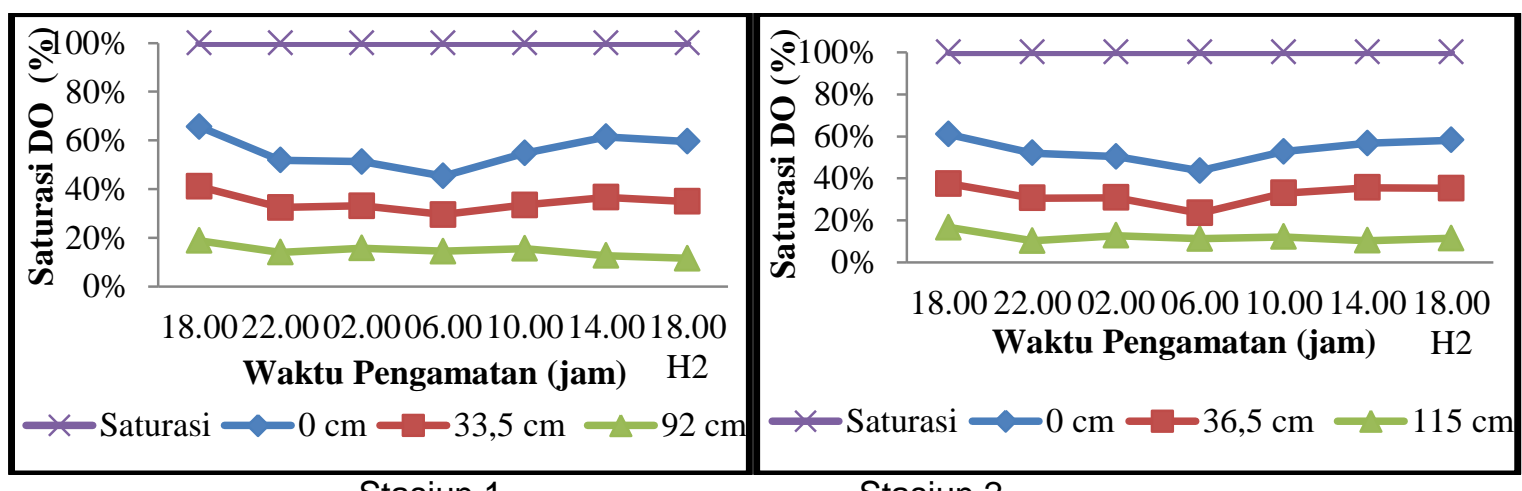

Stasiun $1 \quad$ Stasiun 2

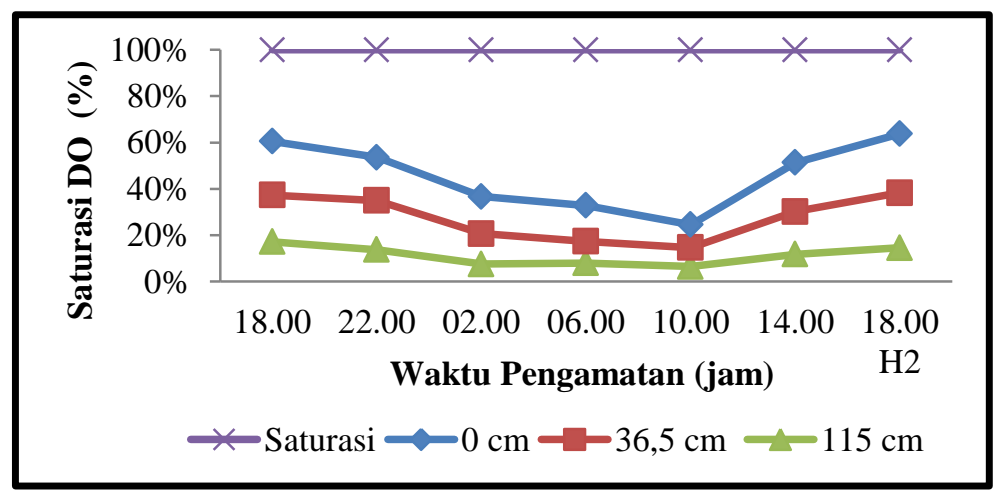

Stasiun 3

Gambar 5. Saturasi oksigen terlarut di DKG

Dilihat dari hasil grafik pada Gambar 6 , konsumsi total pada setiap stasiun mengalami peningkatan seiring dengan bertambahnya kedalaman perairan. Pada stasiun 1 dan 2
(Gambar 6) di lapisan permukaan, konsumsi total masih bernilai negatif kemudian meningkat dengan bertambahnya kedalaman. Konsumsi oksigen terlarut total yang paling 
besar berada pada kedalaman kompensasi di setiap stasiun. Konsumsi oksigen terlarut total terbesar adalah pada stasiun 3 sebesar 0,68 $\mathrm{mg} / \mathrm{l}$.

Keadaan perbandingan antara konsumsi total dan produksi total secara umum pada stasiun 1, 2 dan 3 menunjukkan bahwa telah terjadi defisit oksigen di perairan Danau Kelapa Gading dikarenakan pada saat pengamatan nilai fotosintesis lebih kecil dibandingkan dengan nilai respirasi. Hal ini terutama terjadi pada lapisan kedalaman mendekati dasar perairan. Pada kondisi ini, suplai oksigen yang berasal selain dari fotosintesis sangat dibutuhkan.

Persen saturasi oksigen pada setiap pengamatan di Danau Kelapa Gading menunjukkan tidak adanya konsentrasi oksigen terlarut yang mencapai oksigen terlarut jenuh (super saturasi). Kadar persen saturasi tertinggi berada pada lapisan permukaan yaitu sebesar 71,30 \%. Keadaan under saturasi yang terjadi pada setiap stasiun menunjukkan bahwa di perairan tersebut masih memungkinkan adanya tambahan oksigen ke dalam perairan melalui difusi dari udara bebas. Menurut Effendi (2003), pada kondisi jenuh, tidak ada oksigen yang mengalami difusi dari udara ke dalam air dan sebaliknya.

Kejenuhan oksigen yang diamati pada perairan menunjukkan seberapa besar oksigen yang terdapat di perairan. Persen saturasi terendah berada pada lapisan kedalaman kompensasi sebesar $26,54 \%$ yang terjadi pada pukul 06.00.

Produksi dan konsumsi total oksigen terlarut selama 24 Jam

Pengamatan produksi oksigen selama 24 jam pada setiap stasiun hanya terukur sebanyak 3 kali pengamatan selama adanya cahaya matahari sementara untuk pengamatan konsumsi oksigen terukur sebanyak 6 kali. Fotosintesis total ditunjukkan dengan grafik GPP total di setiap stasiunnya disandingkan dengan nilai konsumsi total selama 24 jam (Gambar 7).

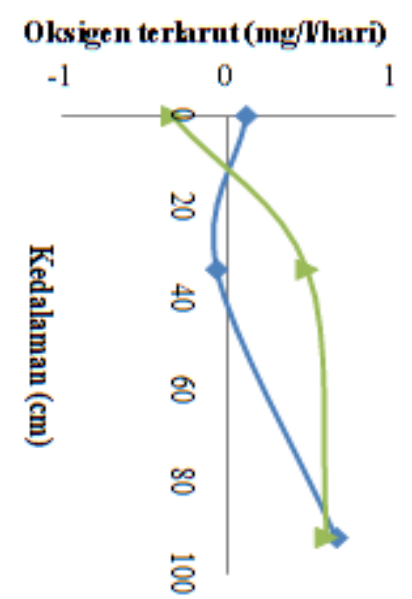

Stasiun 1
Olaigen terharnt (mp/Vhari)

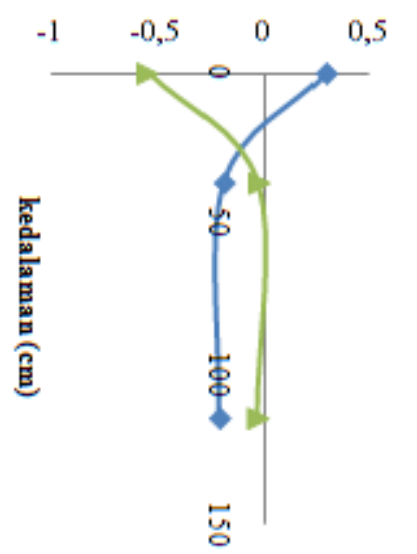

Stasiun 2
Olaiggen terbarnt (mg/Vhari)

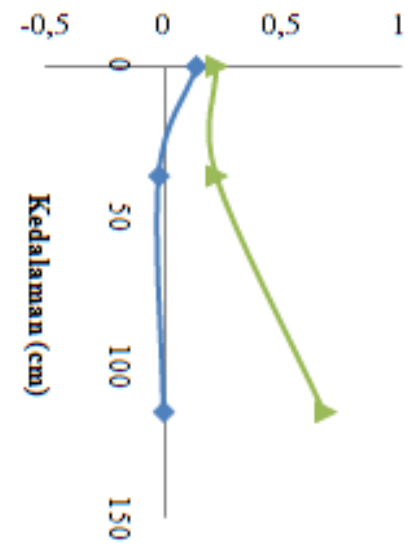

Stasiun 3

$$
\begin{aligned}
& \multimap \text { GPP total } \\
& - \text { Konsumsi total }
\end{aligned}
$$

Gambar 6. Grafik produksi dan konsumsi total oksigen terlarut selama 24 jam

Pengamatan konsumsi total dan nilai GPP total yang terukur pada masing-masing stasiun menunjukkan konsumsi total semakin meningkat dengan bertambahnya kedalaman perairan. Konsumsi total ini semakin meningkat diduga karena aktivitas dekomposisi bahan organik yang juga mempengaruhi oksigen terlarut pada lapisan tersebut. Nilai GPP total yang terukur hanya tinggi pada lapisan permukaan. Hal ini disebabkan pada lapisan permukaan masih ada cahaya matahari yang mampu membantu proses fotosintesis. Sementara pada lapisan selanjutnya yang diamati, nilai GPP total semakin menurun kecuali pada stasiun 1 kembali meningkat pada kedalaman $92 \mathrm{~cm}$. Hal ini disebabkan tingkat konsumsi oksigen oleh mikroorganisme di kedalaman $92 \mathrm{~cm}$ cenderung lebih kecil dan pada kedalaman ini jumlah fitoplankton yang ditemukan lebih tinggi di banding permukaan. 
Menurut Adiwilaga et al., (2009) konsumsi total dan produksi total secara umum pada stasiun 1,2 dan 3 menunjukkan bahwa telah terjadi defisit oksigen di perairan Danau Kelapa Gading dikarenakan pada saat pengamatan nilai fotosintesis lebih kecil dibandingkan dengan nilai respirasi di beberapa kedalaman. Hal ini terutama terjadi pada lapisan kedalaman mendekati dasar perairan. Pada kondisi ini, suplai oksigen yang berasal selain dari fotosintesis sangat dibutuhkan. Apabila keadaan ini terus berlanjut, maka kandungan oksigen di perairan akan semakin kecil. Dengan demikian, akan semakin sedikit organisme yang mampu hidup pada perairan tersebut.

\section{Kesimpulan}

Kondisi suhu secara vertikal di Danau Kelapa Gading menunjukan nilai yang cukup tinggi sampai $34,5{ }^{\circ} \mathrm{C}$ terutama pada lapisan permukaan dan menurun seiring dengan bertambahnya kedalaman. Kondisi ketersediaan DO di Danau Kelapa Gading menunjukkan konsentrasi tertinggi di lapisan permukaan sebesar 5,12 $\mathrm{mg} / \mathrm{l}$ dan menurun dengan bertambahnya kedalaman dan pada saat waktu pengamatan pukul 06.00 WIB sebesar 0,88 mg/l sampai $2 \mathrm{mg} / \mathrm{l}$.

Kelayakan suhu untuk kehidupan organisme akuatik di perairan Danau Kelapa Gading terhitung masih layak karena ikan tropis masih hidup normal pada suhu $30^{\circ} \mathrm{C}$ $35^{\circ} \mathrm{C}$. Kelayakan oksigen terlarut yang terhitung selama pengamatan menunjukkan bahwa ketersediaan DO di Danau Kelapa Gading masih layak untuk kedalaman sampai $36,5 \mathrm{~cm}$. Pada kedalaman mendekati dasar, ketersediaan oksigen terlarut terutama pada malam hari telah terjadi defisit oksigen ditandai dengan besarnya nilai konsumsi dibanding dengan nilai produksi oksigen. Perlu

dilakukannya penelitian lanjutan mengenai analisis kondisi oksigen terlarut secara vertikal terkhusus untuk parameter $\mathrm{BOD}_{5}$, nitrat dan fosfat dan mengenai laju dekomposisi bahan organik sisa pakan dan kotoran ikan dari kegiatan pemeliharaan berbagai jenis ikan yang terakumulasi di dasar perairan danau.

\section{Ucapan Terima Kasih}

Penulis mengucapkan terima kasih kepada tim Danau Kelapa Gading atas bantuan pengambilan data di lapangan. Bapak Syahril Sam Rao yang telah memberikan izin selaku pengelola Danau Kelapa Gading dan membantu kegiatan penelitian.

\section{Daftar Pustaka}

Adiwilaga, E.M., Hariyadi, S., Niken T.M. Pratiwi. 2009. Perilaku Oksigen Terlarut Selama 24 Jam Pada Lokasikaramba Jaring Apung $\mathrm{Di}$ Waduk Saguling, Jawa Barat. Limnotek 16 (2): 109-118.

Ambrosetti, W., Barbanti, L. 2001. Temperature, heat content, mixing and stability in Lake Orta: a pluriannual investigation. Journal of Limnology 60(1): 60-68.

American Public Health Association (APHA). 2012. Standard Methods for The Examination of Water and Waste Water. 22nd ed. Baltimore, MD. 1081 p. Washington DC.

Araoye, P.A. 2009. The Seasonal Variation of $\mathrm{pH}$ and Dissolved Oxygen $\left(\mathrm{DO}_{2}\right)$ Concentration in Asa Lake Ilorin, Nigeria. International Journal of Phsyical Science 4(5): 271-274

Boyd, C.E., Licthkoppler, F. 1979. Water Quality Management in Pond Fish Culture. Research and Development Series No. 22. Project AID/DSAN-G 0039. Auburn University, Alabama. 30 pp.

Chang, W.Y.B., Ouyang, H. 1988. Dynamics of Dissolved Oxygen and Vertical Circulation in Fish Ponds. Aquaculture Elsevier Science Publisher, Netherlands.

Effendi, H. 2003. Telaah Kualitas Air bagi Pengelolaan Sumberdaya dan Lingkungan Perairan. Kanisius, Yogyakarta.

Goldmen, C.R. Horne, A.J. 1983. Limnology. Mc Graw Hill International Book Company. Tokyo. 646 p.

Herdendorf, C.E. 1982. Feature Article Large Lakes Of The World. Journal of Great Lakes Research 8(3):379-412.

Katsev, S., Arthur A. Aaberg, Sean A. Crowe, dan Robert E. Hecky. 2014. Recent Warming of Lake Kivu. PLoS ONE 9(10):

e109084. doi:10.1371/journal.pone.0109084.

Lukman., Ridwansyah, I. 2010. Kajian Kondisi Morfometri Dan Beberapa Parameter Stratifikasi Perairan Danau Toba. Jurnal Limnotek 17 (2): 17 (2) :158170.

Muhtadi, A., Wahyuningsih, H., Zaharuddin, N., Sihaloho, A. 2016. Status Kualitas 
Air dan Kesuburan Perairan Danau Kelapa Gading Kota Kisaran Provinsi Sumatera Utara. Makalah di sampaikan pada Dies Natalis USU ke64, 18-19 Agustus 2016 di Medan

Nakamura, Y., Hayakawa, N. 1991. Modelling of thermal stratification in lakes and coastal seas. Hydrology of Natural and Ntanmade Lakes (Proceedings of the Vienna Symposium, August 1991). IAHS Publ. no. 206,1991

Pal, M., Samal, N.R., Roy, P.K., Malabika, B. Roy. 2014. Temperature and dissolved oxygen stratification in the lake Rudrasagar: Preliminary investigations. Sustainability, Agri, Food and Environmental Research 2(1): 1-12, 2014

Read, J.S., Rose, K.C. 2013. Physical responses of small temperate lakes to variation in dissolved organic carbon concentrations. Limnology and Oceanography 58(3): 921-931.

Reebs, S.G. 2009. Oxygen and Fish Behaviour. Universite de Moncton, Canada.

Ridoan, R., Muhtadi, A., Patana, P. 2016. Morfometri Danau Kelapa Gading Kota Kisaran, Kabupaten Asahan Provinsi Sumatera Utara. Depik 5 (2) : 77-84.

Salmin. 2005. Oksigen Terlarut (DO) dan Kebutuhan Oksigen Biologi (BOD) sebagai Salah Satu Indikator untuk menentukan Kualitas Perairan. Jurnal Oseana. Volume 30 (3): 21-26.

Siagian, M., Asmika, A. Simarmata. 2014. Profil Vertikal Oksigen terlarut di Danau Pinang Luar (Oxbow lake) Kecamatan Siak Hulu, Kabupaten Kampar, Provinsi Riau. Jurnal Akuatika 5 (1): 16-20.

Siagian, M., Asmika, A. Simarmata. 2015. Profil Vertikal Oksigen terlarut di Danau Oxbow Pinang Dalam Desa Buluh Cina-Siak Hulu, Kabupaten Kampar, Provinsi Riau. Jurnal Akuatika 6 (1): 87-94.

Wetzel, R.G., Likens, G.E. 1991. Limnological Analyses. 2nd. Springer-Verlag. New York. $391 \mathrm{p}$. 